\title{
Effects of dietary boron on performance, egg production, egg quality and some bone parameters in layer hens
}

\author{
C. Mızrak ${ }^{\#}$, E. Yenice, M. Can, U. Yıldırım and Z. Atik \\ Poultry Research Institute, Sehit Cem Ersever Caddesi, 06042, Yenimahalle, Ankara, Turkey
}

\begin{abstract}
In this study dietary boron at different doses $(0,25,50,100$ and $200 \mathrm{mg} / \mathrm{kg}$ feed $)$ was supplemented to layers from 4 to 64 weeks of age. There was no significant difference between treatments with respect of mortality, egg production, egg weight, egg mass and cracked eggs. Significant increases were observed in body weight as age rose. Body weight was not affected by dietary boron supplementation at 16 and 40 weeks of age. At 64 weeks of age boron additions of 50,100 and $200 \mathrm{mg} / \mathrm{kg}$ to the diet resulted in significant lower body weights than that of the control group. Egg quality parameters; albumen height and Haugh units, were improved when 25 or $50 \mathrm{mg}$ boron/ $\mathrm{kg}$ diet was supplemented above the other treatments. Shape index, shell thickness, shell breaking strength were not affected by treatments, though $25 \mathrm{mg}$ boron $/ \mathrm{kg}$ diet tended to increase shell breaking strength. Tibia bone strength and phosphorus content in the tibia and femur were not affected by boron supplementation. Boron supplementation at 25 and $50 \mathrm{mg} / \mathrm{kg}$ significantly increased femur bone strength, and ash and calcium content of the tibia and femur bones. Concentration of boron in bone increased with the increase in dietary boron.
\end{abstract}

Keywords: Calcium, phosphorus, fowls, bone strength, Haugh units, tibia

${ }^{\#}$ Corresponding author. E-mail: chmizrak@gmail.com, cengizhanmizrak@hotmail.com

\section{Introduction}

Micro elements and their deficiencies are of great importance in farm animal nutrition. Cereals used in poultry diets may be deficient in $\mathrm{Cu}, \mathrm{Mn}, \mathrm{Zn}$ and Se. Since the 1920's it is known that boron is an essential element for higher plants. It has also been shown that boron plays a role in the metabolism of mineral, bone, enzymes and steroid hormones (Okuyan, 1997; WHO, 1998) and would thus have an influence on animal and human nutrition.

In bone metabolism, boron interacts with $\mathrm{Ca}$, vitamin $\mathrm{D}$ and $\mathrm{Mg}$ (Chapin et al., 1998). In animals and plants, boron affects at least 26 enzymes involved in substrate metabolism, insulin release, oxidation and immune systems (Hunt, 1998). Furthermore, boron was shown to increase the level of some steroid hormones and prevents atherosclerosis, joint deformations and osteoporosis (Naghii \& Saman, 1997a), and boron has antioxidant properties (Lee et al., 1978). An increase in dietary boron content was found to increase the concentrations of blood oestrogen, testosterone hormones, serum ionized $\mathrm{Ca}$ and lipid levels, as well as Ca excretion, but decreases the incidence of vitamin D and $\mathrm{Mg}$ deficiencies (Nielsen et al., 1987; Naghii \& Saman, 1997b). When chemicals containing boron were fed to rats for 14 days, blood low-density lipoprotein (LDL), cholesterol and triglyceride levels decreased significantly, while high-density lipoprotein (HDL) synthesis increased in hepatocytes by lowering LDL synthesis (Hall et al., 1989).

In nature boron is generally present in the form of borate. Plant tissues usually contain $30-50 \mathrm{mg}$ boron/kg DM (Argust, 1998), while animal tissues contain 5 - $6 \mathrm{mg}$ boron/kg DM (Okuyan, 1997). The highest concentrations of boron, ranging from $4.3-17.9 \mathrm{mg} / \mathrm{kg} \mathrm{DM}$, were found in human hair, bone and nails. Although a high boron dose may have lethal effects on an animal, the deficiency of this element caused insufficient growth and abnormal bone development (Naghii, 1999). Fruits, vegetables and legumes are good sources of boron (Sutherland et al., 1998), while whole grains contain very little boron, though grains are widely used in poultry diets (WHO, 1998).

Although boron is not considered to be an essential micronutrient for poultry and other farm animals, $2 \mathrm{mg} / \mathrm{kg}$ of this element is recommended for poultry diets (NRC, 1994). Nielsen (1988) found that the supplementation of $0.3-0.4 \mathrm{mg}$ boron $/ \mathrm{kg}$ is beneficial in the mineral metabolism of chicks, and for pullets at a level of about $1 \mathrm{mg}$ boron $/ \mathrm{kg}$ diet. In other studies boron increased bone strength, prevented joint 
abnormalities and increased inner and outer egg qualities. However these effects of boron are variable depending on management, genotype, productive traits, age of birds and nutrient content of diets, as well as dietary level of boron and its source. Considering all these factors, it seems necessary to investigate the effects of boron supplementation on layer hens over their lifetime. This study was conducted to establish the effects of different levels of boron in the diets of laying hens from early age to maturity, on their growth, production and the accumulation of boron and other element in bodily tissues.

\section{Material and Methods}

Female chickens (Barred Rock egg type strain) were kept in brooders and fed a starter diet. At four weeks of age five levels of boron were included in their diets to constitute five experimental treatments $(0,25,50,100$ and $200 \mathrm{mg}$ boron $/ \mathrm{kg}$ diet). The pullets were moved to grower cages and each treatment consisted of six replicates of 33 birds per replicate. A total 990 birds was used. Grower cages were four floored and $70 \times 110 \mathrm{~cm}$ in size. At 16 weeks of age the hens were transferred to individual layer cages. The layer cages were three floored and $25 \times 47 \mathrm{~cm}$ in size, and each equipped with an automatic feeder and a manure disposer. After 16 weeks, each replication consisted of 24 pullets, totalling 720 pullets.

The first phase of the experiment was divided into three periods (1) growing (4 - 10 weeks), (2) developing (11 - 16 weeks) and (3) pre-laying (17 - 20 weeks) periods. The second phase consisted of two stages: Stage 1 (21 - 40 week of age) and Stage 2 (41 - 64 week of age). Throughout the study the birds were fed diets balanced to be isonitrogenous and isoenergetic, based on NRC (1994) standards (Table 1). The nutrient content of experimental diets was analyzed by AOAC (1984) procedures and ME was calculated (Close \& Menke, 1986). Boric acid (containing 18\% boron) was used in the study. Feed and water were offered ad libitum, while illumination was controlled according to the guidelines for layer hens.

At the beginning of the experimental period (at 4 weeks of age) all pullets per replication were weighed collectively. At weeks 16, 40 and 64 the hens were weighed individually. Mortalities, egg production, egg weight and cracked and broken eggs were recorded daily. Feed intake was determined every fortnight. Egg mass and feed conversion ratios were calculated, using the parameters, egg weight and feed intake:

Daily egg mass $(\mathrm{g} / \mathrm{hen})=$ Egg production (hen-day, \%) x egg weight $(\mathrm{g}) / 100$;

Feed conversion ratio $(\mathrm{g}$ feed/g egg) $=$ Daily feed intake $(\mathrm{g} / \mathrm{hen}) /$ Daily egg mass $(\mathrm{g} / \mathrm{hen})$.

For determining egg quality parameters, 36 eggs per treatment were collected once every four weeks. Egg parameters were shape index, shell thickness, shell strength, egg albumen height and Haugh unit, which were determined $24 \mathrm{~h}$ after collection of the eggs. Egg shape index was determined by equipment that measures the width: length ratio as a percentage. Shell thickness was determined without membrane, using a Mitutoyo digital micrometer (digital 395 series with sensitivity $0.001 \mathrm{~mm}$ sensitivity) by taking measurement from two ends of an egg and in the middle of egg. An arithmetic average was calculated. Breaking strength was measured, using a Futura resistant tool in Newton scale units. Albumen height was measured by Futura equipment electronically. A Haugh unit was calculated according to the formula given below (Haugh, 1937):

Haugh unit $=100 \log$ (albumen height $+7.57-1.7$ egg weight ${ }^{0.37}$ )

(Albumen height in $\mathrm{mm}$; egg weight in $\mathrm{g}$ ).

At the end of the study, six hens per treatment were slaughtered humanely and their tibias and femurs were dissected. The meat on the bones was removed physically and fat, using an ether solvent. The bones were then dried at $60{ }^{\circ} \mathrm{C}$ for $24 \mathrm{~h}$. The bones were subjected to a breaking strength test, using the Instron Universal Machine (Shimadzu-Ag-50KNG Autograph) according to the "three point binding" method in Newton scale units. The bones were ashed overnight in a furnace at $550{ }^{\circ} \mathrm{C}$ to determine ash, $\mathrm{Ca}$ and $\mathrm{P}$ (AOAC, 1990) concentrations. Feed and bone samples were digested in closed teflon vessels using microwave heating, where-upon the boron content was determined through inductively coupled plasma atomic emission spectrometry (ICP-AES) (Kalra, 1998).

Parametric percentage data such as survival rate and egg production were ArcSin transformed, followed by One-Way ANOVA analysis of GLM (SPSS, version 10.01). Analysis of variance was performed for body weight of hens based on the repeated factorial arrangement of treatments (Gill, 1986). Regression analyses were performed in MINITAB (version 14). Means were separated by Duncan's test and the level of significance for all comparisons was set at $\mathrm{P}<0.05$. 
Table 1 Feed ingredients and nutrient composition $(\mathrm{g} / \mathrm{kg})$ of the experimental diets during the different stages of the study

\begin{tabular}{|c|c|c|c|c|c|}
\hline & \multicolumn{5}{|c|}{ Diets } \\
\hline & $\begin{array}{l}\text { Grower } \\
(4-10 \mathrm{wk})\end{array}$ & $\begin{array}{l}\text { Developer } \\
(11-16 \mathrm{wk})\end{array}$ & $\begin{array}{c}\text { Egg starter } \\
(17-20 \mathrm{wk})\end{array}$ & $\begin{array}{c}\text { Layer } \\
\text { Stage } 1 \\
(21-40 \mathrm{wk}) \\
\end{array}$ & $\begin{array}{c}\text { Layer } \\
\text { Stage } 2 \\
(41-64 \text { wk) }\end{array}$ \\
\hline \multicolumn{6}{|l|}{ Feed ingredients } \\
\hline Yellow maize & 401 & 365 & 305 & 331 & 357 \\
\hline Wheat & 200 & 200 & 200 & 250 & 250 \\
\hline Barley & 93 & 100 & 100 & - & - \\
\hline Soyabean meal & 160 & 129 & 167 & 219 & 152 \\
\hline Full-fat soya & - & - & - & 40 & 50 \\
\hline Sunflower meal & 100 & 100 & 100 & - & - \\
\hline Razmol & 7.06 & 70.18 & 44.51 & 14.74 & 58.4 \\
\hline Plant oil & - & - & 19.82 & 30 & 11.45 \\
\hline Limestone & 10.87 & 10.72 & 36.58 & 88.3 & 98 \\
\hline Dicalcium phosphate & 14.68 & 15.25 & 17.95 & 16.2 & 13 \\
\hline $\mathrm{NaCl}$ & 3.5 & 3.5 & 3.5 & 3.5 & 3.5 \\
\hline DL-Methionine & 1.98 & 0.97 & 1.14 & 2.34 & 2.15 \\
\hline L-Lysine & 2.91 & 0.38 & - & 0.42 & - \\
\hline Anticoccidial & 0.5 & 0.5 & - & - & - \\
\hline Antioxidant & 0.5 & 0.5 & 0.5 & 0.5 & 0.5 \\
\hline Vitamin premix $^{1}$ & 1 & 1 & 1 & 1 & 1 \\
\hline Mineral premix ${ }^{2}$ & 1 & 1 & 1 & 1 & 1 \\
\hline Salmonella inhibitor & 2 & 2 & 2 & 2 & 2 \\
\hline \multicolumn{6}{|l|}{ Nutrient content } \\
\hline \multicolumn{6}{|l|}{ Chemical analysis } \\
\hline Crude protein & 179 & 163 & 173 & 162 & 152 \\
\hline Dry matter & 891 & 893 & 898 & 906 & 896 \\
\hline Crude fibre & 50.9 & 52.3 & 52.0 & 29.4 & 30.5 \\
\hline Crude ash & 58.0 & 51.0 & 82.0 & 130.4 & 135.3 \\
\hline Ether extract & 24.0 & 23.0 & 42.5 & 47.5 & 33.5 \\
\hline Total sugar & 44.2 & 44.8 & 47.6 & 49.4 & 45.7 \\
\hline Starch & 430 & 428 & 373 & 414 & 422 \\
\hline Boron, $\mathrm{mg} / \mathrm{kg}$ & 13.49 & 11.10 & 15.32 & 26.55 & 26.98 \\
\hline \multicolumn{6}{|l|}{ Calculated nutrient content } \\
\hline $\mathrm{ME}, \mathrm{MJ} / \mathrm{kg}$ & 11.78 & 11.47 & 11.39 & 11.82 & 11.57 \\
\hline Calcium & 10.0 & 10.0 & 20.0 & 38.0 & 42.0 \\
\hline Available phosphorus & 4.0 & 4.0 & 4.5 & 4.0 & 3.5 \\
\hline Methionine & 4.7 & 3.5 & 3.8 & 4.8 & 4.4 \\
\hline Methionine+Cystine & 7.7 & 6.5 & 6.9 & 7.8 & 7.2 \\
\hline Lysine & 9.8 & 7.2 & 7.8 & 9.1 & 7.5 \\
\hline Tryptophan & 1.9 & 1.7 & 1.9 & 2.0 & 1.8 \\
\hline
\end{tabular}

\section{Results and Discussion}

In the present study survival rate was not affected by boron supplementation (Table 2). Although there is no evidence in the literature regarding detrimental effects of $400 \mathrm{mg}$ boron $/ \mathrm{kg}$ diet on fowls or pigs, high doses of boron supplementation resulted in its accumulation in internal organs, tissues and bones. (Rossi et al., 1993a; Wilson \& Ruszler, 1998; Kurtoğlu et al., 2001). 
The performance of pullets and layers is given in Tables 2, 3 and 4 . At the beginning of the experiment (four weeks of age) body weights of the pullets did not differ between treatments $(\mathrm{P}>0.05)$. Significant increases were observed in body weight with an increase in age $(\mathrm{P}<0.05)$. Simple and multiple regression equations and $\mathrm{R}^{2}$ of body weight of hens by weeks in $16-64$ week of age were:

$16 \mathrm{wk} \mathrm{BW}=837+0.205(40 \mathrm{wk} \mathrm{BW})+0.0547(64 \mathrm{wk} \mathrm{BW}),\left(\mathrm{R}^{2}=0.20\right)$

$16 \mathrm{wk} \mathrm{BW}=857+0.251(40 \mathrm{wk} \mathrm{BW}),\left(\mathrm{R}^{2}=0.20\right)$

$16 \mathrm{wk} \mathrm{BW}=940+0.205(64 \mathrm{wk} \mathrm{BW}),\left(\mathrm{R}^{2}=0.15\right)$

$40 \mathrm{wk} \mathrm{BW}=506+0.734(64 \mathrm{wk} \mathrm{BW}),\left(\mathrm{R}^{2}=0.62\right)$

Body weight was not affected by dietary boron supplementation at 16 and 40 weeks of age $(\mathrm{P}>0.05)$. At 64 weeks of age boron additions of 50,100 and $200 \mathrm{mg} / \mathrm{kg}$ to the diet resulted in lower $(\mathrm{P}<0.05)$ body weights than that of the control group.

During the egg laying period, boron supplementation did not affect feed intake, egg production, egg weight, egg mass, feed efficiency and incidence of broken and cracked eggs $(\mathrm{P}>0.05)$. It was previously reported that $250 \mathrm{mg} / \mathrm{kg}$ of dietary boron did not have any detrimental effect on body weight and feed intake of laying hens while $400 \mathrm{mg}$ boron $/ \mathrm{kg}$ decreased body weight gain and feed intake (Rossi et al., 1993a; Wilson \& Ruszler, 1996; 1998; Kurtoğlu et al., 2002; Eren et al., 2004).

Table 2 Survival rate of hens during the study and body weight of pullets at four weeks of age (mean \pm s.e.)

\begin{tabular}{lccc}
\hline \multirow{2}{*}{ Boron, $\mathrm{mg} / \mathrm{kg}$} & \multicolumn{2}{c}{$\begin{array}{c}\text { Survival rate } \\
\%\end{array}$} & $\begin{array}{c}\text { Body weight* } \\
\mathrm{g} / \text { pullet }\end{array}$ \\
\cline { 2 - 4 } & $4-21$ week & $21-64$ week & Week 4 \\
\hline & $99.8 \pm 0.17$ & $99.7 \pm 0.21$ & $209 \pm 2.4$ \\
25 & $99.8 \pm 0.17$ & $99.8 \pm 0.17$ & $213 \pm 3.5$ \\
50 & $99.7 \pm 0.21$ & $99.7 \pm 0.21$ & $212 \pm 2.1$ \\
100 & $99.8 \pm 0.17$ & $100.0 \pm 0.00$ & $204 \pm 2.8$ \\
200 & $99.7 \pm 0.21$ & $99.7 \pm 0.21$ & $215 \pm 2.7$ \\
P values & 0.912 & 0.606 & 0.071 \\
\hline
\end{tabular}

* Pen weight divided by number of birds.

Table 3 Individual body weights of hens at 16, 40 and 64 weeks of age (mean \pm s.e.)

\begin{tabular}{lccc}
\hline \multirow{3}{*}{ Boron, $\mathrm{mg} / \mathrm{kg}$} & \multicolumn{3}{c}{ Body weight, g per hen } \\
\cline { 2 - 4 } & Week 16 & Week 40 & Week 64 \\
\hline \multirow{2}{*}{0} & $1370^{\mathrm{cA}} \pm 10.1$ & $2036^{\mathrm{bA}} \pm 18.0$ & $2134^{\mathrm{aA}} \pm 19.0$ \\
25 & $1384^{\mathrm{cA}} \pm 10.0$ & $1990^{\mathrm{bA}} \pm 17.9$ & $2083^{\mathrm{aAB}} \pm 19.0$ \\
50 & $1357^{\mathrm{bA}} \pm 10.2$ & $2043^{\mathrm{aA}} \pm 18.2$ & $2047^{\mathrm{aBC}} \pm 19.2$ \\
100 & $1324^{\mathrm{bA}} \pm 10.0$ & $2009^{\mathrm{aA}} \pm 17.8$ & $2011^{\mathrm{aC}} \pm 18.8$ \\
200 & $1384^{\mathrm{bA}} \pm 10.1$ & $2034^{\mathrm{aA}} \pm 18.0$ & $2051^{\mathrm{aBC}} \pm 19.0$
\end{tabular}

*The difference between the treatments indicated through capitals in the same column and the difference between the weeks indicated by lower case letters in the same row are significant $(\mathrm{P}<0.05)$.

Boron did not affect egg production (Table 4). This agrees with reported results by Rossi et al. (1993a), Wilson \& Ruszler (1996; 1998), Kurtoğlu et al. (2002) and Eren et al. (2004), that boron supplementation between $5 \mathrm{mg} / \mathrm{kg}$ and $250 \mathrm{mg} / \mathrm{kg}$ did not affect egg production significantly. Although boron supplementation did not affect egg weight and consequently egg mass in the present study, additions of 100 and $200 \mathrm{mg}$ boron $/ \mathrm{kg}$ tended to decrease egg weight $(\mathrm{P}=0.092)$ and mass $(\mathrm{P}=0.30)$. Dietary supplementation of 200,250 and $400 \mathrm{mg} / \mathrm{kg}$ did not affect egg weight in some studies (Rossi et al., 1993a) 
but decreased it in others (Wilson \& Ruszler, 1998; Eren et al., 2004). The present levels of boron supplementation $(0,50,100$ and $250 \mathrm{mg} / \mathrm{kg})$ did not affect feed efficiency, in agreement with results reported by Kurtoğlu et al. (2002). Eren et al. (2004) recorded that at 200 and $400 \mathrm{mg}$ boron $/ \mathrm{kg}$ the incidence of broken and cracked egg ratios increased.

Egg quality characteristics are given in Table 5. In the present study, boron supplementations did not affect $(\mathrm{P}>0.05)$ the outer egg quality parameters such as shape index, shell thickness and shell strength. Shell thickness was not affected by dietary boron supplementation, which agrees with the report by Rossi et al. (1993a). However, the inner egg quality parameters such as albumen height and Haugh units were increased $(\mathrm{P}<0.05)$ by 25 and $50 \mathrm{mg}$ boron/kg supplementation. The Haugh unit is a known indicator of egg freshness and is related to shelf life. The improvement in these two parameters may indicate that boron supplementation can improve egg quality by increasing its shelf life.

Bone strength and the chemical composition of the femur and tibia are presented in Table 6. Dietary boron supplementation at 25 and $50 \mathrm{mg} / \mathrm{kg}$ increased $(\mathrm{P}<0.05)$ femur strength compared to the other treatments. The strength of the tibia was not affected by boron supplementation $(\mathrm{P}>0.05)$. Dietary

Table 4 Egg production (mean \pm s.e) of laying hens during production period (22 - 64 weeks)

\begin{tabular}{lcccccc}
\hline $\begin{array}{c}\text { Boron, } \\
\mathrm{mg} / \mathrm{kg}\end{array}$ & $\begin{array}{c}\text { Egg } \\
\text { production, } \\
\text { hen-day, } \%\end{array}$ & $\begin{array}{c}\text { Egg weight } \\
\mathrm{g}\end{array}$ & $\begin{array}{c}\text { Daily egg } \\
\text { mass } \\
\mathrm{g} / \mathrm{h} \text { en }\end{array}$ & $\begin{array}{c}\text { Daily feed } \\
\text { intake } \\
\mathrm{g} / \mathrm{hen}\end{array}$ & $\begin{array}{c}\text { FCR } \\
\text { (g feed/g egg) }\end{array}$ & $\begin{array}{c}\text { Broken \& } \\
\text { cracked egg, } \\
\%\end{array}$ \\
\hline 0 & $75.4 \pm 0.6$ & $58.1 \pm 0.29$ & $43.8 \pm 0.46$ & $112.3 \pm 0.7$ & $2.56 \pm 0.04$ & $0.36 \pm 0.06$ \\
25 & $75.3 \pm 0.6$ & $58.0 \pm 0.23$ & $43.6 \pm 0.22$ & $111.6 \pm 0.6$ & $2.56 \pm 0.02$ & $0.28 \pm 0.04$ \\
50 & $75.2 \pm 0.7$ & $58.5 \pm 0.35$ & $43.9 \pm 0.39$ & $114.4 \pm 1.1$ & $2.61 \pm 0.05$ & $0.32 \pm 0.03$ \\
100 & $75.1 \pm 0.6$ & $57.5 \pm 0.47$ & $43.2 \pm 0.36$ & $111.5 \pm 0.3$ & $2.58 \pm 0.03$ & $0.43 \pm 0.05$ \\
200 & $75.0 \pm 0.7$ & $57.3 \pm 0.13$ & $42.9 \pm 0.40$ & $113.0 \pm 0.7$ & $2.63 \pm 0.04$ & $0.47 \pm 0.09$ \\
P values & 0.99 & 0.092 & 0.300 & 0.066 & 0.534 & 0.235 \\
\end{tabular}

FCR - feed conversion ratio.

Table 5 Egg quality (mean \pm s.e.) of hens supplemented with different doses of boron

\begin{tabular}{|c|c|c|c|c|c|}
\hline Boron, $\mathrm{mg} / \mathrm{kg}$ & Shape index & $\begin{array}{c}\text { Shell thickness } \\
10^{-2} \mathrm{~mm}\end{array}$ & $\begin{array}{l}\text { Shell strength } \\
\text { N }\end{array}$ & $\begin{array}{c}\text { Albumen } \\
\text { height, mm }\end{array}$ & Haugh units \\
\hline \multicolumn{6}{|c|}{ Egg quality parameters in laying Stage I (22 - 40 weeks) } \\
\hline 0 & $78.3 \pm 0.4$ & $31.48 \pm 0.40$ & $37.24 \pm 0.90$ & $6.38 \pm 0.12$ & $76.6^{\mathrm{b}} \pm 1.3$ \\
\hline 25 & $78.0 \pm 0.3$ & $31.65 \pm 0.33$ & $39.04 \pm 0.66$ & $6.76 \pm 0.13$ & $81.9^{\mathrm{a}} \pm 1.0$ \\
\hline 50 & $77.5 \pm 0.3$ & $31.82 \pm 0.33$ & $37.03 \pm 0.60$ & $6.71 \pm 0.15$ & $79.5^{\mathrm{ab}} \pm 1.3$ \\
\hline 100 & $77.8 \pm 0.3$ & $31.60 \pm 0.45$ & $37.88 \pm 0.73$ & $6.52 \pm 0.12$ & $78.2^{\mathrm{ab}} \pm 1.1$ \\
\hline 200 & $77.8 \pm 0.3$ & $31.02 \pm 0.31$ & $37.14 \pm 0.63$ & $6.67 \pm 0.11$ & $80.6^{\mathrm{ab}} \pm 0.9$ \\
\hline $\mathrm{P}$ values & 0.428 & 0.61 & 0.241 & 0.187 & 0.011 \\
\hline \multicolumn{6}{|c|}{ Egg quality parameters in laying Stage II (41 - 64 weeks) } \\
\hline 0 & $77.3 \pm 0.2$ & $29.04 \pm 0.21$ & $32.13 \pm 0.49$ & $4.44^{\mathrm{b}} \pm 0.12$ & $62.8^{\mathrm{b}} \pm 1.1$ \\
\hline 25 & $77.5 \pm 0.2$ & $29.35 \pm 0.18$ & $33.27 \pm 0.45$ & $4.66^{\mathrm{ab}} \pm 0.09$ & $64.4^{\mathrm{ab}} \pm 1.0$ \\
\hline 50 & $77.0 \pm 0.2$ & $29.20 \pm 0.26$ & $32.02 \pm 0.52$ & $4.94^{\mathrm{a}} \pm 0.08$ & $67.1^{\mathrm{a}} \pm 0.7$ \\
\hline 100 & $77.4 \pm 0.2$ & $29.21 \pm 0.15$ & $32.11 \pm 0.50$ & $4.71^{\mathrm{ab}} \pm 0.09$ & $64.9^{\mathrm{ab}} \pm 0.9$ \\
\hline 200 & $77.3 \pm 0.2$ & $28.98 \pm 0.20$ & $32.02 \pm 0.44$ & $4.82^{\mathrm{ab}} \pm 0.11$ & $65.6^{\mathrm{ab}} \pm 1.0$ \\
\hline$P$ values & 0.334 & 0.718 & 0.296 & 0.008 & 0.025 \\
\hline
\end{tabular}

\footnotetext{
$\overline{\mathrm{a}, \mathrm{b}}$ Means within columns with different superscripts differ significantly at $\mathrm{P}<0.05$.
} 
Table 6 Breaking strength and chemical concentration of the tibia and femur bones in hens supplemented with dietary boron

\begin{tabular}{cccccc}
\hline $\begin{array}{l}\text { Boron, } \\
\mathrm{mg} / \mathrm{kg}\end{array}$ & $\begin{array}{c}\text { Breaking strength, } \\
\mathrm{N}\end{array}$ & $\begin{array}{c}\text { Ash } \\
\%\end{array}$ & $\begin{array}{c}\text { Calcium } \\
\%\end{array}$ & $\begin{array}{c}\text { Phosphorus } \\
\%\end{array}$ & $\begin{array}{c}\text { Boron } \\
\mathrm{mg} / \mathrm{kg}\end{array}$ \\
\hline Tibia & & & & & \\
0 & $41.4 \pm 5.4$ & $48.9^{\mathrm{b}} \pm 0.57$ & $17.75^{\mathrm{b}} \pm 0.25$ & $7.95 \pm 0.05$ & $4.17^{\mathrm{e}} \pm 0.17$ \\
25 & $51.3 \pm 1.8$ & $50.0^{\mathrm{b}} \pm 0.29$ & $18.75^{\mathrm{a}} \pm 0.01$ & $7.91 \pm 0.05$ & $8.83^{\mathrm{d}} \pm 0.33$ \\
50 & $47.4 \pm 3.9$ & $53.7^{\mathrm{a}} \pm 0.54$ & $18.25^{\mathrm{ab}} \pm 0.25$ & $7.94 \pm 0.07$ & $12.00^{\mathrm{c}} \pm 0.58$ \\
100 & $51.3 \pm 4.1$ & $50.3^{\mathrm{b}} \pm 0.45$ & $17.75^{\mathrm{b}} \pm 0.25$ & $8.03 \pm 0.02$ & $16.17^{\mathrm{b}} \pm 0.60$ \\
200 & $47.9 \pm 7.4$ & $49.6^{\mathrm{b}} \pm 0.82$ & $16.75^{\mathrm{c}} \pm 0.25$ & $8.05 \pm 0.01$ & $24.33^{\mathrm{a}} \pm 0.17$ \\
P values & 0.621 & 0.001 & 0.001 & 0.218 & 0.0001 \\
\hline Femur & & & & & \\
0 & $35.6^{\mathrm{b}} \pm 6.54$ & $47.5^{\mathrm{b}} \pm 0.58$ & $14.0^{\mathrm{b}} \pm 0.25$ & $7.94 \pm 0.08$ & $2.67^{\mathrm{e}} \pm 0.44$ \\
25 & $74.4^{\mathrm{a}} \pm 9.38$ & $53.7^{\mathrm{a}} \pm 1.73$ & $16.0^{\mathrm{a}} \pm 0.50$ & $8.11 \pm 0.10$ & $7.17^{\mathrm{d}} \pm 0.60$ \\
50 & $76.7^{\mathrm{a}} \pm 11.0$ & $54.3^{\mathrm{a}} \pm 2.65$ & $16.0^{\mathrm{a}} \pm 0.50$ & $8.09 \pm 0.06$ & $12.0^{\mathrm{c}} \pm 0.58$ \\
100 & $42.2^{\mathrm{ab}} \pm 5.43$ & $49.4^{\mathrm{ab}} \pm 0.09$ & $16.0^{\mathrm{a}} \pm 0.50$ & $8.07 \pm 0.05$ & $19.7^{\mathrm{b}} \pm 0.60$ \\
200 & $47.7^{\mathrm{ab}} \pm 7.02$ & $49.7^{\mathrm{ab}} \pm 1.32$ & $15.0^{\mathrm{ab}} \pm 0.01$ & $8.01 \pm 0.66$ & $27.0^{\mathrm{a}} \pm 0.50$ \\
P values & 0.010 & 0.044 & 0.019 & 0.506 & 0.0001 \\
\hline
\end{tabular}

$\overline{\mathrm{a}-\mathrm{e}}$ Means within columns with different superscripts differ significantly at $\mathrm{P}<0.05$.

supplementation of $50 \mathrm{mg}$ boron/ $\mathrm{kg}$ increased the ash content of the bones, while $25 \mathrm{mg}$ boron/ $\mathrm{kg}$ increased the Ca concentration and $200 \mathrm{mg}$ boron $/ \mathrm{kg}$ the boron concentrations of the tibia and femur $(\mathrm{P}<0.05)$ without affecting the $\mathrm{P}$ content of these bones $(\mathrm{P}>0.05)$.

In this study dietary boron supplementations at 25 and $50 \mathrm{mg} / \mathrm{kg}$ increased the strength of the femur significantly, while the tibia tended to be stronger, though this was not statistically significant. These results are in line with the study of Wilson \& Ruszler (1997) who reported that 50 and $100 \mathrm{mg}$ boron/kg in pullet diets increased bone breaking strength. Wilson \& Ruszler (1998) found that $200 \mathrm{mg}$ boron/kg diet increased the breaking strength of the tibia and radius bones of layer hens. However, their previous studies (Wilson \& Ruszler, 1995; 1996) showed no effect of boron supplementation on bone breaking strength.

Dietary boron supplementation $(25 \mathrm{mg} / \mathrm{kg})$ increased the tibia Ca concentration while 25,50 and 100 $\mathrm{mg}$ boron $/ \mathrm{kg}$ supplementation resulted in an increased $(\mathrm{P}<0.05)$ femur Ca content, though $200 \mathrm{mg}$ boron $/ \mathrm{kg}$ did not affect the $\mathrm{Ca}$ concentration of the bones. A similar pattern was observed for bone ash content $(\mathrm{P}<0.05)$. On the other hand, dietary boron supplementation did not affect $\mathrm{P}$ concentrations in the tibia and femur. The increased bone ash content of the hens corresponds with that of some studies (Qin \& Klandorf, 1991; Wilson \& Ruszler, 1997; Rossi et al., 1993b; Kurtoğlu et al., 2005), but not in others (Wilson \& Ruszler 1998; Fassani et al., 2004). Wilson \& Ruszlar (1998) observed that the addition of 50, 100, 200 and $400 \mathrm{mg}$ boron $/ \mathrm{kg}$ to layer diets decreased bone $\mathrm{Ca}$ and $\mathrm{P}$ concentrations while Fassani et al. (2005) observed no response in bone Ca concentration when 30,60, 90, 120 and $150 \mathrm{mg}$ boron/ $\mathrm{kg}$ were added to a broiler diet. Similarly, the addition of 5 and $15 \mathrm{mg}$ boron/ $\mathrm{kg}$ to a piglet diet did not affect bone Ca concentration but increased P concentration linearly. Armstrong \& Spears (2001) reported that dietary boron supplementation did not affect $\mathrm{Ca}$ and $\mathrm{P}$ absorption and accumulation in the bones of pigs. In a study by Kurtoğlu et al. (2005) broiler chicks were fed diets containing 5 and $25 \mathrm{mg}$ boron $/ \mathrm{kg}$. They observed that the bone Ca concentration increased and $\mathrm{Zn}$ concentration decreased with an increase in boron supplementation, while bone $\mathrm{Fe}$ and $\mathrm{Cu}$ concentrations did not change. These differences in the literature might be attributed to animal species, productive type, age, experimental period, dietary content and other minerals in the diet. In the present study boron supplementation seemed to have enhanced bone $\mathrm{Ca}$ and $\mathrm{P}$ metabolism by cancelling out the negative consequences of egg shell formation on bone formation, and consequently increased bone strength.

Increased concentrations of boron in bone recorded in the present study are in agreement with previous observation on the accumulation of boron in soft and bone tissues (Rossi et al., 1993b; Wilson \& Ruszler, 1995; 1996; 1998; Lu Lin \& Yuan Ying 2003; Kurtoğlu et al., 2005). Supplementation of boron up to $200 \mathrm{mg} / \mathrm{kg}$ increased boron accumulation six fold in the tibia and ten fold in the femur. Wilson \& Ruszlar (1998) reported similar results in which the supplementation of 50, 100, 200 and $400 \mathrm{mg}$ boron/kg increased 
the boron accumulation in bones eight fold, while Kurtoğlu et al. (2005) reported an 1.5 to two fold increase when boron content of the diet was increased from 5 and $25 \mathrm{mg} / \mathrm{kg}$. Lu Lin \& Yuan Ying (2003) added 0, 20, $40,60,80,100$ and $120 \mathrm{mg}$ boron/ $\mathrm{kg}$ to a broiler diet and found an increase in boron concentration in the blood, liver, breast meat and tibia with an increase in boron intake.

In the present study, boron accumulations in bones did not cause any health problems or a reduction in productive performance of the layers. These results are in line with previous studies (Rossi et al., 1993b, Wilson \& Ruszler 1995; 1996; 1998; Lin \& Ying 2003; Kurtoğlu et al., 2005).

\section{Conclusion}

In this study, the supplementation of $25-200 \mathrm{mg}$ boron $/ \mathrm{kg}$ to hens during a period of $4-64$ weeks of age did not affect the health status and productive performance of the layers. However, inner egg quality parameters, albumen height and Haugh units were improved by the supplementation of 25 and $50 \mathrm{mg}$ boron $/ \mathrm{kg}$. In practice, chickens in layer cages develop decreased Ca utilization when getting older and often develop leg problems (osteoporosis, etc.) due to their high level of egg production, leading to economic losses. In the current study, 25 and $50 \mathrm{mg}$ boron $/ \mathrm{kg}$ resulted in the accumulation of $\mathrm{Ca}$ in bones, supported Ca-P metabolism and improved egg shell quality.

In conclusion, boron supplementation at 25 and $50 \mathrm{mg} / \mathrm{kg}$ improved egg quality. Further studies on the inclusion of boron in layer diets are suggested which could include different levels of $\mathrm{Ca}$ and $\mathrm{P}$ and anatomical and histological investigations. It is suggested that up to $50 \mathrm{mg}$ boron $/ \mathrm{kg}$ could be included in the diets of egg producing hens.

\section{Acknowledgement}

This study was funded by the National Boron Institute (BOREN) in Turkey.

\section{References}

AOAC, 1984. Official Methods of Analysis of the Association of Official Analytical Chemists. Washington, D.C., USA.

AOAC, 1990. Official Methods of Analysis of the Association of Official Analytical Chemists. The William Byrd. Press, Inc., Richmond, Virginia, USA.

Argust, P., 1998. Distribution of boron in the environment, Biol. Tr. Elem. Res. 66, 131-143.

Armstrong, T.A. \& Spears, J.W., 2001. Effect of dietary boron on growth performance, calcium and phosphorus metabolism, and bone mechanical properties in growing barrows. J. Anim. Sci. 79, 3120-3127.

Chapin, R.E., Ku, W.W., Kenney, M.A. \& McCoy, H., 1998. The effects of dietary boric acid on bone strength in rats. Biol. Tr. Elem. Res. 66, 395-399.

Close, S.W. \& Menke, K.H., 1986. Selected Topics in Animal Nutrition. 170+A 85. Wielinger Straße 52, D-8133, Feldafins.

Eren, M., Uyanik, F. \& Küçükersan, S., 2004. The influence of dietary boron supplementation on egg quality and serum calcium, inorganic phosphorus, magnesium levels and alkaline phosphate activity in laying hens. Res. Vet. Sci. 76, 203-210.

Fassani, E.J, Bertechini, A.G, Brito, J.A.G., Kato, R.K., Fialho, E.T. \& Geraldo, A., 2004. Boron supplementation in broiler diets. Braz. J. Poult. Sci. 4 (4), 213-217.

Gill, J.L., 1986. Repeated measurement: Sensitive tests for experiments with few animals. J. Anim. Sci. 63, 943-954.

Hall, I.H., Spielvogal, B.F. \& Griffin, T.S., 1989. The effects of boron hyperlipidemic agents on LDL and HDL receptor binding and related enzyme activates of rat hepatocytes, aorta cells and human fibroblasts. Res. Comm. Chem. Pathol. Pharmocol. 65, 297-317.

Haugh, R.R., 1937. The Haugh Unit for measuring egg quality. United States Egg Poultry Magazine 43, 522-573.

Hunt, C.D., 1998. One possible role of dietary boron in higher animals and humans. Biol. Tr. Elem. Res. 66, 205-225.

Kalra, Y.P., 1998. Handbook of Reference Methods for Plant Analysis. Soil and Plant Analysis Council. Salem, MA 01970 USA. 
Kurtoğlu, V., Kurtoğlu, F. \& Coşkun, B., 2001. Effects of boron supplementation of adequate and inadequate vitamin $\mathrm{D}_{3}$-containing diet on performance and serum biochemical characters of broiler chickens. Res. Vet. Sci. 71, 183-187.

Kurtoğlu, V., Kurtoğlu, F., Coskun, B., Seker, E., Balevi, T. \& Cetingul, I.S., 2002. Effects of boron supplementation on performance and some serum biochemical parameters in laying hens. Revve de Medicine Veterinaire 153 (12), 823-828.

Kurtoğlu, F., Kurtoğlu, V., Celik, I., Kececi, T. \& Nizamlioglu, M., 2005. Effects of dietary boron supplementation on some biochemical parameters, peripheral blood lymphocytes, splenic plasma cells and bone characteristics of broiler chicks given diets with adequate or inadequate cholecalciferol (vitamin D3) content. Br. Poult. Sci. 46, 87-96.

Lee, I.P., Sherins, R.J. \& Dixon, R.L., 1978. Evidence for induction of germinal aplasia in male rats by environmental exposure to boron. Tox. Appl. Pharmacol. 45, 577-590.

Lu, Lin \& Yuan, Y., 2003. Effect of boron on the performance and deposition of boron in tissues and organs of broilers. Acta Zoonutrimenta Sinica 15 (1), 49-53.

Naghii, M.R. \& Samman, S., 1997a. The effect of boron supplementation on its urinary excretion and selected cardiovascular risk factors in healthy male subjects. Biol. Tr. Elem. Res. 56, 273-286.

Naghii, M.R. \& Samman, S., 1997b. The effect of boron plasma testosterone and plasma lipids in rats. Nutr. Res. 17, 523-531.

Naghii, M.R., 1999. The significance of dietary boron, with particular reference to athletes. Nutr. Health 13, 31-37.

Nielsen, F.H., Hunt, C.D., Mullen, L.M. \& Hunt, J.R.. 1987. Effect of dietary boron on mineral, estrogen, and testosterone metabolism in postmenopausal women. FASEB. J. 87, 394-397.

Nielsen, F.H., 1988. Boron - an overlooked element of potential nutritional importance. Nutr. Today (Jan/Feb), 4-7.

NRC, 1984. National Research Council, Nutrients requirements of poultry, 8th ed. Washington, D.C.: National Academic Pres, USA. 71 pp.

NRC, 1994. National Research Council. Nutrients requirements of poultry, 9th ed. Washington, D.C.: National Academic Press, USA. 155 pp.

Okuyan, M.R., 1997. Biochemistry of Animal Nutrition. Ankara Üniversitesi Ziraat Fakültesi Yayınları, Yayın no: 1491, Ders kitabı: 450, Ankara. pp. 350 (in Turkish).

Qin, X. \& Klandorf, H., 1991. Effect of dietary boron supplementation on egg production, shell quality, and calcium metabolism in aged broiler breeder hens. Poult. Sci. 70, 2131-2138.

Rossi, A.F., Miles, R.D., Bootwalla, S.M., Wilson, H.R. \& Eldred, A.R., 1993a.The effect of feeding two sources of boron on broiler breeder performance. Poult. Sci. 72, 1931-1934.

Rossi, A.F, Miles, R.D., Damron, B.I. \& Flunker, L.K., 1993b. Effects of dietary boron supplementation on broilers. Poult. Sci. 72, 2124-2130.

Sutherland, B., Strong, P. \& King, J.C., 1998. Determining human dietary requirements for boron. Biol. Tr. Elem. Res. 66, 193-204.

WHO, 1998. International Programme on Chemical Safety, Environmental Health Criteria 204, Boron, Ohio, USA. pp. 1-20.

Wilson, J.H. \& Ruszler, P.L., 1995. Effects of dietary boron on poultry bone strength. Transactions of the ASAE, 38, 167-170.

Wilson, J.H. \& Ruszler, P.L., 1996. Effects of dietary boron supplementation on laying hens. Br. Poult. Sci. 37, 723-729.

Wilson, J.H. \& Ruszler, P.L., 1997. Effects of boron on growing pullets. Biol. Tr. Elem. Res. 56 (3), 287-294.

Wilson, J.H. \& Ruszler, P.L., 1998. Long term effect of boron layer bone strength and production parameters. Br. Poult. Sci. 39, 11-15. 